\title{
Performance Test of Three-Phase Brushless Direct Current Motor Axial Flux with Differences Diameter of Neodymium Type Permanent Magnet
}

\author{
Alif Willis Nurmalia ${ }^{1 *)}$, Widyono $\mathrm{Hadi}^{2)}$, and Widya Cahyadi ${ }^{3)}$ \\ ${ }^{1,2,3)}$ Department of Electrical Engineering, Jember University, Indonesia. \\ Corresponding Email: *)alifwillis@ gmail.com
}

\begin{abstract}
Technology that is growing rapidly and innovations that have sprung up in the electrical field today are driving the use of electricity as a source of energy to do work. Electric motor is one component that is very popular in the industrial world and households that are useful to human life. In addition to DC motors and induction motors, there are also 3 phase brushless direct current (BLDC) motors which are a type of synchronous motor where magnetic fields are produced by rotor and stator at the same frequency. The rotor is a moving part of the brushless direct current motor which is a place of permanent magnet called a pole. This paper discusses the performance of brushless direct current 3 phase axial flux motors with different diameters of neodymium type permanent magnets. Tests carried out using neodymium permanent magnets with diameters of $15 \mathrm{~mm} \times 2 \mathrm{~mm}$ and $20 \mathrm{~mm} \times 2 \mathrm{~mm}$ were tested without using a load and using load. The parameters used in testing motor performance include speed, torque, and motor power with a source voltage of $12 \mathrm{~V}, 16 \mathrm{~V}, 20 \mathrm{~V}$, and $24 \mathrm{~V}$. The test results shows that the speed value of a BLDC motor using permanent magnets with a size of $20 \mathrm{~mm} \times 2 \mathrm{~mm}$ is greater than that of permanent magnets of $15 \mathrm{~mm} \times 2 \mathrm{~mm}$. The same thing applies to the value of the power produced while, for the value of torque when the motor uses a permanent magnet of $15 \mathrm{~mm} \times 2 \mathrm{~mm}$ will be greater than that of a motor using a permanent magnet of $20 \mathrm{~mm} \times 2 \mathbf{m m}$.
\end{abstract}

Keywords: Motor, BLDC, Neodymium, Diameter

\section{Pendahuluan}

Teknologi sekarang ini terutama pada bidang industri di dunia sangat berkembang dengan pesat selain itu, teknologi yang semakin canggih dan inovasi yang mulai beragam pada bidang elektro sehingga hampir semua peralatan industri maupun rumah tangga membutuhkan listrik sebagai suplai sumber tenaga untuk bekerja. Motor listrik merupakan komponen utama pada peralatanperalatan industri maupun rumah tangga yang memudahkan hidup manusia. Walaupun motor listrik sudah dikenal efisien dan bebas polusi, perlu adanya pengembangan dan riset untuk mendapatkan performa motor listrik yang efisien dan juga optimal. Motor listrik merupakan sebuah perangkat elektromagnetis yang mengubah energi listrik menjadi energi mekanik yang digunakan untuk memutar impeller pompa, fan, atau blower menggerakkan kompresor, mengangkat bahan, dll
[1]. Berdasarkan sumber tegangan dibedakan menjadi dua jenis yaitu motor listrik AC dan motor listrik DC. Selain motor DC dan motor AC terdapat pula motor brushless direct current yang merupakan pilihan ideal untuk aplikasi yang memerlukan keandalan yang tinggi, efisiensi tinggi, dan rasio volume power tinggi. Motor brushless direct current 3 fasa fluks aksial merupakan motor sinkron AC 3 fasa dengan magnet permanen pada rotor dimana disebut brushless direct current karena pada implementasinya menggunakan sumber DC sebagai sumber energi utama. Tujuan dari pemberian tegangan AC 3 fasa ialah menciptakan medan magnet putar stator untuk menarik magnet rotor dimana medan magnet putar yang dihasilkan stator dan medan magnet yang dihasilkan oleh putaran rotor memiliki frekuensi yang sama [2].

Penelitian sebelumnya membahas rancang motor brushless direct current 3 fasa fluks aksial. Pada penelitian tersebut membahas mengenai rancangan konstruksi motor brushless direct current 3 fasa fluks aksial dan membandingkan hasilnya dengan motor brushless direct current 3 fasa sensorless tipe out-runner. Hasil dari penelitian tersebut ialah pada motor brushless direct current axial 3 fasa fluks axial memiliki variasi tegangan motor yang banyak sedangkan, motor brushless direct current 3 fasa sensorless tipe out-runner hanya memiliki satu variasi tegangan motor. [3]

Paper ini membahas mengenai performa motor brushless direct current 3 fasa fluks aksial dengan variasi perbedaan diameter magnet permanen neodymium dengan ukuran $15 \mathrm{~mm}$ x $2 \mathrm{~mm}$ dan $20 \mathrm{~mm}$ x $2 \mathrm{~mm}$. Pengujian yang dilakukan sebanyak 2 kali dengan kondisi motor tanpa menggunakan beban dan menggunakan beban dengan 4 variasi tegangan sumber. Paper ini meninjau nilai kecepatan dan torsi yang dihasilkan saat melakukan pembandingan 2 magnet permanen jenis neodymium yang memiliki perbedaan dalam ukuran.

\section{MetodoloGi}

\section{A. Motor Brushless Direct Current 3 Fasa Fluks Aksial}

Motor brushless direct current 3 fasa fluks aksial merupakan salah satu jenis motor sinkron yang tidak mengalami slip karena menggunakan hall effect sebagai komutator sehingga tidak mengalami rugi-rugi yang disebabkan oleh sikat arang. 


\section{1) Kecepatan Motor}

Pada sisi rotor dari motor brushless direct current 3 fasa fluks aksial terdapat magnet permanen yang biasa disebut pole dimana jumlah pole akan menghasilkan fluks magnet sehingga dapat memutar sebuah roda [4]. Nilai kecepatan motor dapat didapatkan dengan menggunakan rumus [5]:

$$
N s=\frac{120 f}{p}
$$

$$
\begin{aligned}
& \text { Ns }=\text { Kecepatan putar rotor }(\mathrm{RPM}) \\
& \mathrm{P}=\text { Jumlah kutub } \\
& \mathrm{F}=\text { Frekuensi }(\mathrm{Hz})
\end{aligned}
$$

2) Torsi

Torsi merupakan gaya yang digunakan untuk menggerakkan sesuatu dengan jarak dan arah tertentu yang didapat

$$
\begin{aligned}
& \boldsymbol{T}=\boldsymbol{r} \times \boldsymbol{F} \\
\mathrm{T} & =\operatorname{Torsi}(\mathrm{Nm}) \\
\mathrm{F} & =\operatorname{Gaya}(\mathrm{N}) \\
\mathrm{R} & =\operatorname{Jari} \text {-jari rotor }(\mathrm{m})
\end{aligned}
$$

\section{3) Gaya Putar Motor}

Gaya tolak menolak magnet terjadi pada saat magnet dengan kutub yang memiliki kutub yang sama saat magnet tersebut didekatkan. Untuk menentukan gaya ditentukan dengan rumus [6]

$$
F=\frac{k \cdot m_{1} m_{2}}{x^{2}}
$$

$\mathrm{K}=10^{-7}$

$m_{1}=$ Medan magnet pada rotor (Am)

$m_{2}=$ Medan magnet pada stator (Am)

$\mathrm{X}=$ Jarak antar motor dan stator $(\mathrm{m})$

Dalam menentukan kuat kutub magnet menggunakan perhitungan yang sama yaitu

$$
m_{1}=H \times A
$$

$\mathrm{H}=$ Intensitas medan magnet $(\mathrm{A} / \mathrm{m})$

$\mathrm{A}=$ Luas penampang magnet $\left(\mathrm{m}^{2}\right)$

Nilai $\mathrm{H}$ merupakan perkalian nilai $\mathrm{B}$ dengan 795774,71 yang merupakan konversi nilai 1 Tesla [7]. Untuk menentukan kuat kutub magnet pada kumparan dapat diketahui dengan rumus

$$
\begin{aligned}
& m_{2}=H \times A \\
& H=\left(\frac{I . N}{L}\right)
\end{aligned}
$$

$\mathrm{I}=\operatorname{Arus}(\mathrm{A})$

$\mathrm{N}$ = Jumlah Kumparan

$\mathrm{L}=$ Panjang Kumparan (m)

\section{4) Daya Input}

Daya input merupakan daya listrik yang digunakan untuk keperluan menggerakkan mesin listrik atau peralatan lainnya[8]. Untuk daya input motor listrik 3 phase dapat dirumuskan:

$$
\begin{array}{r}
\text { Pin }=\sqrt{3} \cdot \text { Va } \cdot I a \\
\mathrm{Va}=\text { Tegangan }(\mathrm{V})
\end{array}
$$

$$
\text { Ia }=\operatorname{Arus}(\mathrm{A})
$$

\section{5) Daya Output}

Daya output merupakan daya mekanis yang dihasilkan pada motor [9]. Daya output motor didapatkan dengan rumus:

$$
\begin{gathered}
\text { Pout }=T \omega_{s} \\
\text { Pout }=T \cdot 2 \pi \cdot \frac{n s}{60} \\
\mathrm{~T}=\text { Torsi }(\mathrm{Nm}) \\
\omega_{s}=\text { Kecepatan Putar Rotor }(\mathrm{Rad} / \mathrm{s})
\end{gathered}
$$

\section{6) Efisiensi Motor}

Perhitungan efisiensi diperlukan untuk mengetahui performa dari kinerja motor brushless direct current 3 fasa fluks aksial. Efisiensi pada motor brushless direct current 3 fasa fluks aksial berkaitan dengan daya input dan daya output yang dihasilkan oleh motor brushless direct current 3 fasa fluks aksial. Efisiensi motor brushless direct current 3 fasa fluks aksial didapatkan dari persamaan berikut[6]:

$$
\begin{aligned}
& \eta=\frac{\text { Pout }}{\text { Pin }} X 100 \% \\
& \text { Pout = Daya Output }(\mathrm{W}) \\
& \text { Pin = Daya Input }(\mathrm{W})
\end{aligned}
$$

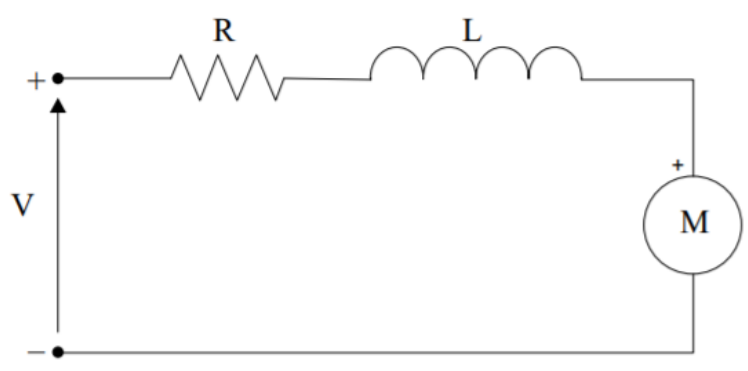

Gambar 1. Rangkaian ekuivalen motor listrik sederhana

\section{B. Perancangan Penelitian}

Penelitian dilakukan di Laboratorium Konversi Energi Listrik, Fakultas Teknik, Universitas Jember. Terdapat tahapan-tahapan perancangan penelitian mengenai performa motor brushless direct current 3 fasa fluks aksial dengan perbedaan diameter magnet permanen dilaksanakan diantaranya ialah menentukan rumusan masalah pada penelitian, menentukan densitas magnet berdasarkan material magnet pada sisi rotor yang ditentukan dengan melakukan pengukuran. Gambar 2 merupakan hasil pengukuran densitas magnet pada magnet permanen neodymium dengan ukuran $15 \mathrm{~mm} \mathrm{x}$ $2 \mathrm{~mm}$ yang bernilai $77.1 \mathrm{mT}$ dan Gambar 3 merupakan hasil pengukuran pada magnet dengan ukuran $20 \mathrm{~mm} \mathrm{x}$ $2 \mathrm{~mm}$ yang bernilai $35.8 \mathrm{mT}$. Tahapan selanjutnya yaitu melakukan pengujian terhadap motor brushless direct current 3 fasa fluks aksial dan membandingkan hasil pengujian terhadap kedua motor dengan perbedaan magnet permanen serta menganalisis hasil pengujian. Pengujian dilakukan sebanyak 2 kali yaitu pengujian motor brushless direct current 3 fasa fluks aksial tanpa menggunakan beban dan dengan menggunakan beban. Masing-masing pengujian menguji 2 variasi magnet 
permanen yaitu mengguakan rotor dengan magnet permanen ukuran $15 \mathrm{~mm}$ x $2 \mathrm{~mm}$ dan $20 \mathrm{~mm}$ x $2 \mathrm{~mm}$.

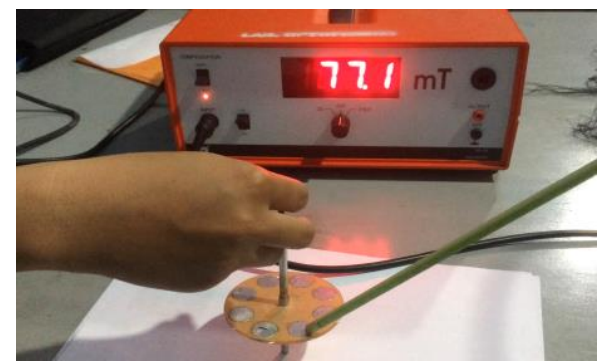

Gambar 2. Hasil pengukuran densitas magnet parmanen $15 \mathrm{~mm} \times 2 \mathrm{~mm}$

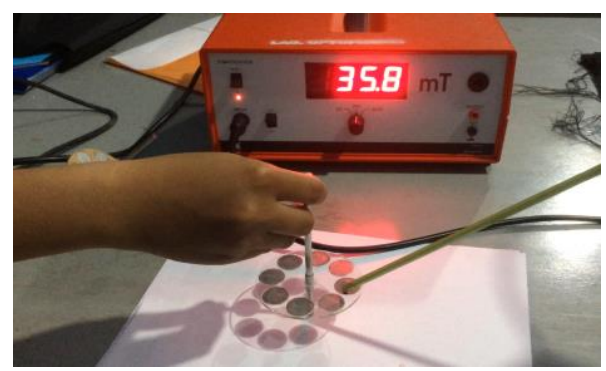

Gambar 3. Hasil pengukuran densitas magnet permanen $20 \mathrm{~mm} \times 2 \mathrm{~mm}$

Pada sistem motor brushless direct current 3 fasa fluks aksial menggunakan sumber tegangan DC yang berasal dari power supply dimana motor brushless direct current 3 fasa fluks aksial menggunakan 8 magnet permanen dan 6 kumparan lilitan yang pada masingmasing kumparan memiliki 450 lilitan dengan kawat email berukuran $0,3 \mathrm{~mm}$. Gambar 4 dan 5 merupakan rancangan rotor pada masing-masing magnet permanen. Magnet permanen yang digunakan memiliki ketebalan yang sama yaitu $2 \mathrm{~mm}$ dengan perbedaan ukuran diameter dimana diameter yang digunakan berukuran $15 \mathrm{~mm}$ dan 20mm. Gambar 4 merupakan rancangan keseluruhan motor brushless direct current 3 fasa fluks aksial. Pada Tabel 1 menunjukan spesifikasi motor yang akan digunakan.

Pada pengujian motor brushless direct current 3 fasa fluks aksial menggunakan beban dilakukan pada masingmasing magnet permanen. Beban yang digunakan untuk pengujian motor brushless direct current 3 fasa fluks aksial menggunakan beban generator axial flux 3 phase dengan LED sebanyak 3 buah dengan resistor $470 \mathrm{Ohm}$. Pemberian beban bertujuan untuk mengetahui performa motor saat dibebani

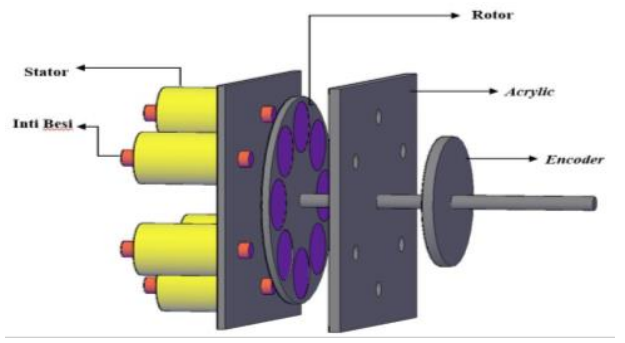

Gambar 4. Rancangan keseluruhan motor brushless direct current 3 fasa fluks aksial

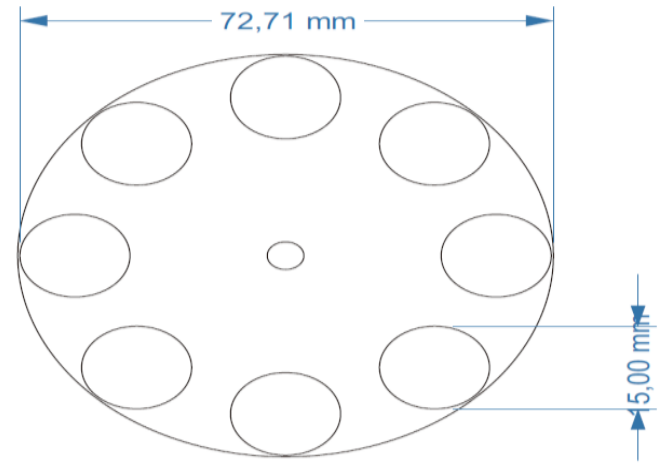

Gambar 5. Rancangan rotor dengan magnet permanen $15 \mathrm{~mm} \times 2 \mathrm{~mm}$

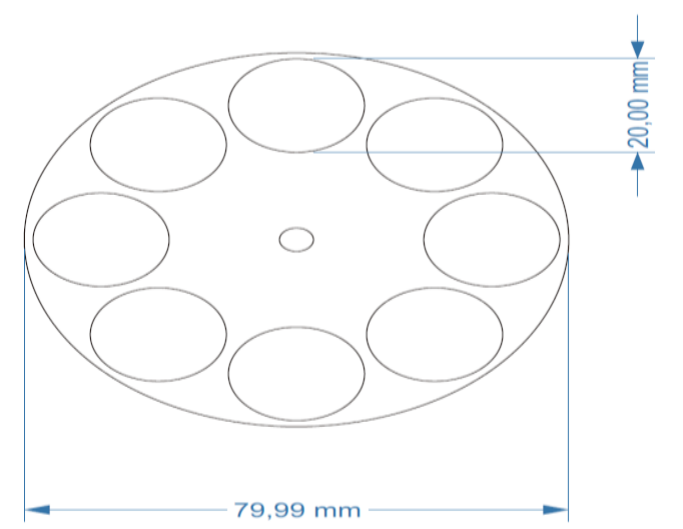

Gambar 6. Rancangan rotor dengan magnet permanen $20 \mathrm{~mm}$ $\mathrm{x} 2 \mathrm{~mm}$

Tabel 1. Spesifikasi Motor Brushless Direct Current 3 Fasa Fluks Aksial

\begin{tabular}{ccc}
\hline Keterangan & Simbol & Nilai \\
\hline Lilitan & $\mathrm{N}$ & 450 lilitan/kumparan \\
\hline Kumparan & $\mathrm{s}$ & 6 Buah \\
\hline Stator & & Tunggal \\
\hline Diameter Rotor 1 & $\mathrm{D}$ & 0,072 meter \\
\hline Diameter Rotor 2 & $\mathrm{D}$ & 0,079 meter \\
\hline Jumlah Magnet & $\mathrm{p}$ & 8 Buah \\
\hline Jumlah Phase & $\mathrm{Nph}$ & 3 Phase \\
\hline Penampang Stator & $\mathrm{P}$ & 0,01 meter \\
\hline & 1 & 0,026 meter \\
\hline Bentuk Magnet & & Silinder \\
\hline Diameter Magnet 1 & $\mathrm{D}$ & 0,015 meter \\
\hline Tebal Magnet 1 & $\mathrm{t}$ & 0,002 meter \\
\hline Diameter Magnet 2 & $\mathrm{D}$ & 0,02 meter \\
\hline Tebal Magnet 2 & $\mathrm{t}$ & 0,002 meter \\
\hline Jarak Rotor dan & $\mathrm{X}$ & 0,005 meter \\
Stator & & \\
\hline
\end{tabular}




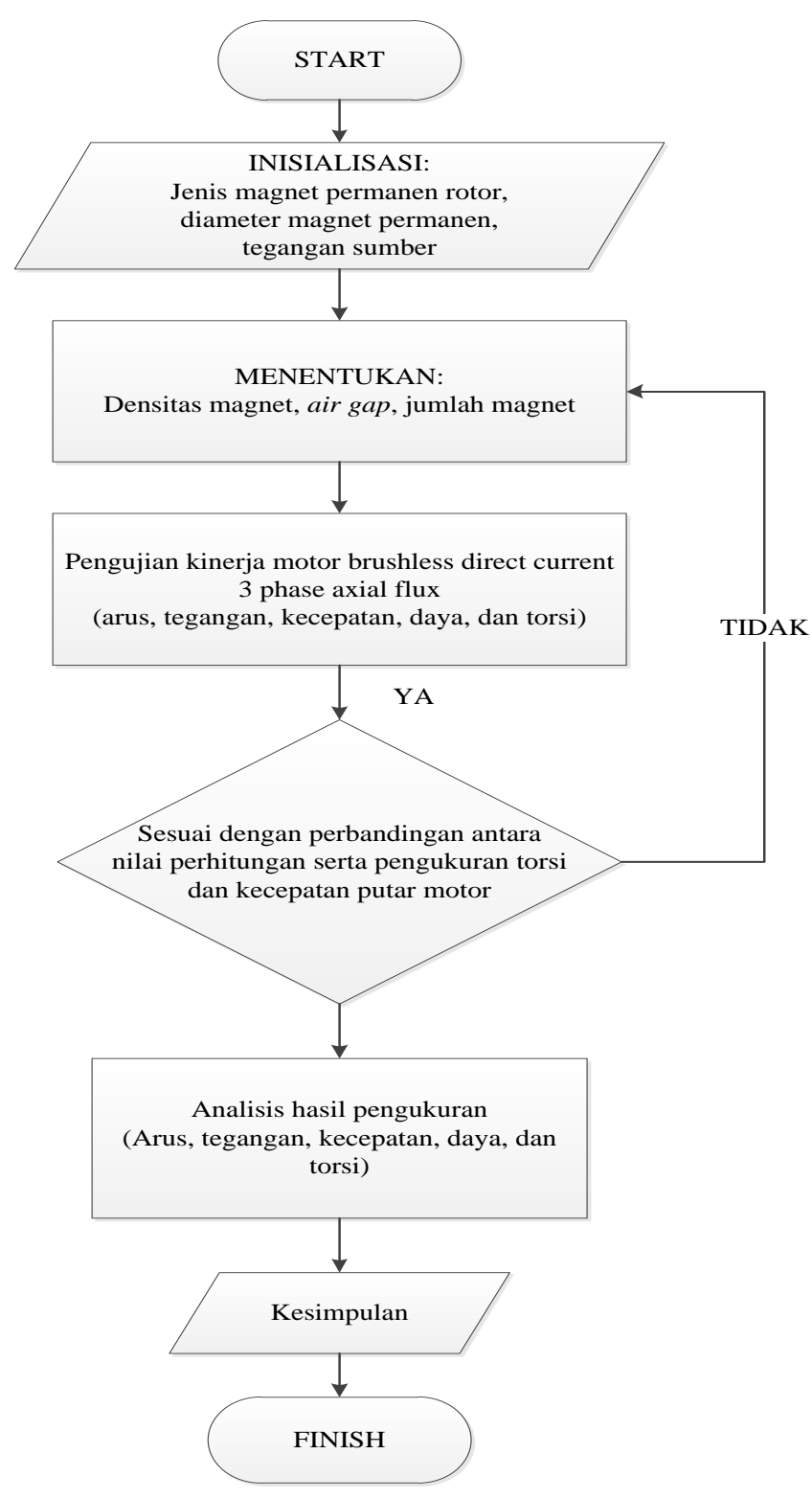

Gambar 7. Flowchart penelitian

\section{HASIL DAN PEMBAHASAN}

Dari penelitian yang telah dilakukan dengan menguji motor brushless direct current 3 fasa fluks aksial dengan perbedaan diameter magnet permanen tanpa menggunakan beban didapatkan data yang terlampir pada Tabel 2 dan 3.

Tabel 2. Hasil pengujian kecepatan motor brushless direct current 3 fasa fluks aksial magnet permanen $15 \mathrm{~mm} \times 2 \mathrm{~mm}$ tanpa beban

\begin{tabular}{ccccc}
\hline $\begin{array}{c}\text { Tegangan } \\
\begin{array}{c}\text { Sumber } \\
\text { (Volt) }\end{array}\end{array}$ & $\begin{array}{c}\text { Tegangan } \\
\text { Motor } \\
\text { (Volt) }\end{array}$ & $\begin{array}{c}\text { Arus } \\
\text { Motor } \\
(\mathrm{A})\end{array}$ & $\begin{array}{c}\text { Frekuensi } \\
(\mathrm{Hz})\end{array}$ & $\begin{array}{c}\text { Kecepatan } \\
(\mathrm{RPM})\end{array}$ \\
\hline 12 & 8,263 & 0,109 & 83,05 & 1246 \\
16 & 11,097 & 0,127 & 107,20 & 1608 \\
20 & 13,943 & 0,145 & 130,20 & 1957 \\
24 & 16,940 & 0,16 & 153,20 & 2300 \\
\hline
\end{tabular}

Tabel 3. Hasil pengujian motor kecepatan brushless direct current 3 fasa fluks aksial magnet permanen $20 \mathrm{~mm}$ x $2 \mathrm{~mm}$ tanpa beban

\begin{tabular}{ccccc}
\hline $\begin{array}{c}\text { Tegangan } \\
\begin{array}{c}\text { Sumber } \\
\text { (Volt) }\end{array}\end{array}$ & $\begin{array}{c}\text { Tegangan } \\
\text { Motor } \\
\text { (Volt) }\end{array}$ & $\begin{array}{c}\text { Arus } \\
\text { Motor } \\
\text { (A) }\end{array}$ & $\begin{array}{c}\text { Frekuensi } \\
(\mathrm{Hz})\end{array}$ & $\begin{array}{c}\text { Kecepatan } \\
(\mathrm{RPM})\end{array}$ \\
\hline 12 & 7,233 & 0,108 & 83,5 & 1251 \\
16 & 10,100 & 0,128 & 111,1 & 1677 \\
20 & 12,967 & 0,145 & 139,6 & 2072 \\
24 & 15,867 & 0,162 & 163,3 & 2454 \\
\hline
\end{tabular}

Dari data pada Tabel 2 dan Tabel 3 diketahui bahwa nilai kecepatan dan nilai frekuensi berbanding lurus dimana saat nilai frekuensi semakin besar maka nilai kecepatan akan semakin besar pula. Saat membandingkan nilai kecepatan dengan nilai tegangan sumber yang sama dari kedua hasil pengujian dengan variasi diameter magnet permanen didapat bahwa nilai kecepatan saat menggunakan magnet permanen $20 \mathrm{~mm}$ x $2 \mathrm{~mm}$ lebih besar dibandingkan dengan nilai kecepatan pada magnet permanen $15 \mathrm{~mm}$ x $2 \mathrm{~mm}$. Hal ini disebabkan oleh perbedaan nilai diameter dari masing-masing magnet dimana pada saat magnet dengan diameter $20 \mathrm{~mm} \times 2 \mathrm{~mm}$ memiliki nilai diameter yang lebih besar dibandingkan dengan diameter magnet permanen $15 \mathrm{~mm}$ x $2 \mathrm{~mm}$. Karena perbedaan frekuensi yang dibaca hall effect menyebabkan nilai kecepatan yang berbeda. Perbedaan nilai kecepatan terhadap tegangan pada motor brushless direct current 3 fasa fluks aksial dapat dilihat pada Gambar 8.

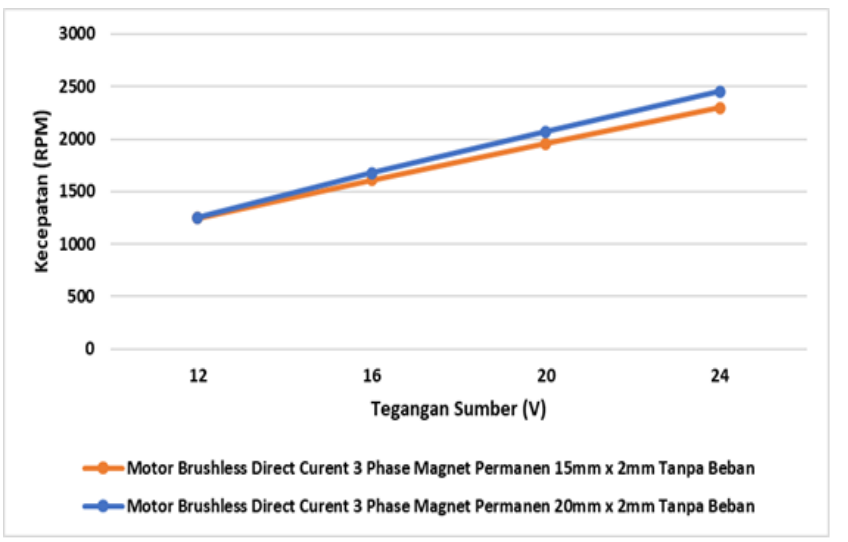

Gambar 8. Karakteristik kecepatan motor terhadap tegangan sumber pada motor brushless direct current 3 fasa fluks aksial dengan perbedaan diameter magnet permanen tanpa beban

Torsi sangat berpengaruh dengan performa dari motor brushless direct current 3 fasa fluks aksial. Pada perhitungan nilai torsi yang dihasilkan pada pengujian motor brushless direct current 3 fasa fluks aksial tanpa beban didapatkan bahwa nilai torsi yang dihasilkan pada saat motor brushless direct current 3 fasa fluks aksial menggunakan magnet permanen $15 \mathrm{~mm}$ x $2 \mathrm{~mm}$ lebih besar dibandingkan dengan motor brushless direct current 3 fasa fluks aksial dengan magnet permanen $20 \mathrm{~mm} \times 2 \mathrm{~mm}$. Nilai hasil perhitungan torsi motor brushless direct current 3 fasa fluks aksial dapat dilihat pada Tabel 4 dan Tabel 5. 
Tabel 4. Hasil pengujian torsi motor brushless direct current 3 fasa fluks aksial magnet permanen $15 \mathrm{~mm}$ x $2 \mathrm{~mm}$ tanpa beban

\begin{tabular}{ccccc}
\hline $\begin{array}{c}\text { Tegangan } \\
\begin{array}{c}\text { Sumber } \\
(\mathrm{V})\end{array}\end{array}$ & $\begin{array}{c}\text { Tegangan } \\
\text { Motor } \\
(\mathrm{V})\end{array}$ & $\begin{array}{c}\text { Arus } \\
\text { Motor } \\
(\mathrm{A})\end{array}$ & $\begin{array}{c}\text { Gaya } \\
(\mathrm{N})\end{array}$ & $\begin{array}{c}\text { Torsi } \\
(\mathrm{Nm})\end{array}$ \\
\hline 12 & 8,263 & 0,109 & 0,320 & 0,012 \\
\hline 16 & 11,097 & 0,127 & 0,373 & 0,013 \\
\hline 20 & 13,943 & 0,145 & 0,426 & 0,015 \\
\hline 24 & 16,940 & 0,16 & 0,470 & 0,017 \\
\hline
\end{tabular}

Tabel 5. Hasil pengujian torsi motor brushless direct current 3 fasa fluks aksial magnet permanen $20 \mathrm{~mm}$ x $2 \mathrm{~mm}$ tanpa beban

\begin{tabular}{ccccc}
$\begin{array}{c}\text { Tegangan } \\
\begin{array}{c}\text { Sumber } \\
(\mathrm{V})\end{array}\end{array}$ & $\begin{array}{c}\text { Tegangan } \\
\text { Motor } \\
(\mathrm{V})\end{array}$ & $\begin{array}{c}\text { Arus } \\
\text { Motor } \\
(\mathrm{A})\end{array}$ & $\begin{array}{c}\text { Gaya } \\
(\mathrm{N})\end{array}$ & $\begin{array}{c}\text { Torsi } \\
(\mathrm{Nm})\end{array}$ \\
\hline 12 & 7,233 & 0,108 & 0,262 & 0,0102 \\
\hline 16 & 10,100 & 0,128 & 0,311 & 0,0121 \\
\hline 20 & 12,967 & 0,145 & 0,352 & 0,0137 \\
\hline 24 & 15,867 & 0,162 & 0,393 & 0,0153 \\
\hline
\end{tabular}

Perbedaan pada nilai torsi pada motor menggunakan magnet permanen $15 \mathrm{~mm}$ x $2 \mathrm{~mm}$ dan $20 \mathrm{~mm}$ x $2 \mathrm{~mm}$ disebabkan nilai gaya yang dihasilkan saat motor dengan magnet permanen $15 \mathrm{~mm}$ x $2 \mathrm{~mm}$ lebih besar dibandingkan dengan motor dengan magnet permanen $20 \mathrm{~mm} \times 2 \mathrm{~mm}$. Nilai gaya dipengaruhi oleh nilai intensitas medan magnet dan luas permukaan magnet permanen. Sehingga nilai torsi dan gaya yang dihasilkan akan berbeda. Perbedaan nilai torsi pada pengujian motor brushless direct current 3 fasa fluks aksial dapat dilihat pada Gambar 9. Nilai tegangan motor, arus motor, kecepatan, dan torsi mempengaruhi nilai daya input dan daya output dari motor brushless direct current 3 fasa fluks aksial. Nilai daya akan mempengaruhi nilai efisiensi dari motor brushless direct current 3 fasa fluks aksial. Tabel 6 dan 7 merupakan hasil perhitungan nilai daya input dan daya output pada pengujian motor brushless direct current 3 fasa fluks aksial tanpa menggunakan beban. Pada tabel tersebut membandingkan nilai daya input saat motor menggunakan magnet permanen $15 \mathrm{~mm}$ x $2 \mathrm{~mm}$ dengan nilai daya input motor menggunakan magnet permanen $20 \mathrm{~mm} \times 2 \mathrm{~mm}$.

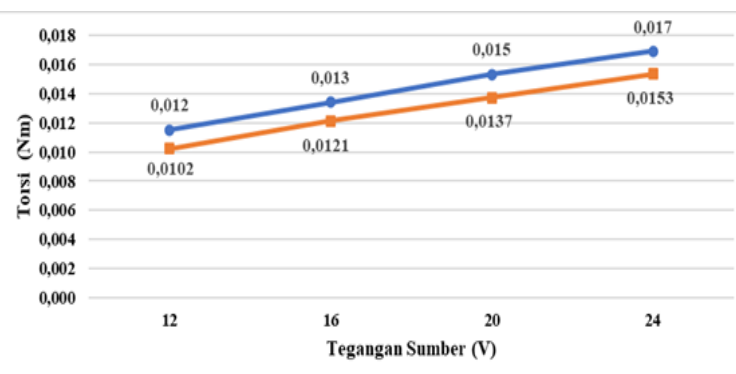

- Motor Brushless Direct Current 3 Phase Magnet Permanen $15 \mathrm{~mm} x 2 \mathrm{~mm}$ - Motor Brushless Direct Current 3 Phase Magnet Permanen $20 \mathrm{~mm} \times 2 \mathrm{~mm}$

Gambar 9. Karakteristik torsi motor terhadap tegangan sumber pada motor brushless direct current 3 phase axial flux dengan perbedaan diameter magnet permanen tanpa beban
Tabel 6. Hasil perhitungan daya motor brushless direct current 3 fasa fluks aksial magnet permanen $15 \mathrm{~mm} \times 2 \mathrm{~mm}$ tanpa beban

\begin{tabular}{cccccc}
\hline $\begin{array}{c}\text { Tegangan } \\
\begin{array}{c}\text { Sumber } \\
(\mathrm{V})\end{array}\end{array}$ & $\begin{array}{c}\text { Tegangan } \\
\text { Motor } \\
(\mathrm{V})\end{array}$ & $\begin{array}{c}\text { Arus } \\
\text { Motor } \\
(\mathrm{A})\end{array}$ & $\begin{array}{c}\text { Torsi } \\
(\mathrm{Nm})\end{array}$ & $\begin{array}{c}\text { Daya } \\
\text { Input } \\
(\mathrm{W})\end{array}$ & $\begin{array}{c}\text { Daya } \\
\text { Output } \\
(\mathrm{W})\end{array}$ \\
\hline 12 & 8,263 & 0,109 & 0,012 & 1,560 & 1,503 \\
\hline 16 & 11,097 & 0,127 & 0,013 & 2,441 & 2,259 \\
\hline 20 & 13,943 & 0,145 & 0,015 & 3,502 & 3,139 \\
\hline 24 & 16,940 & 0,16 & 0,017 & 4,695 & 4,071 \\
\hline
\end{tabular}

Tabel 7. Hasil perhitungan daya motor brushless direct current 3 fasa fluks aksial magnet permanen 20mm x 2mm tanpa beban

\begin{tabular}{cccccc}
\hline $\begin{array}{c}\text { Tegangan } \\
\begin{array}{c}\text { Sumber } \\
(\mathrm{V})\end{array}\end{array}$ & $\begin{array}{c}\text { Tegangan } \\
\text { Motor } \\
(\mathrm{V})\end{array}$ & $\begin{array}{c}\text { Arus } \\
\text { Motor } \\
(\mathrm{A})\end{array}$ & $\begin{array}{c}\text { Torsi } \\
(\mathrm{Nm})\end{array}$ & $\begin{array}{c}\text { Daya } \\
\text { Input } \\
(\mathrm{W})\end{array}$ & $\begin{array}{c}\text { Daya } \\
\text { Output } \\
(\mathrm{W})\end{array}$ \\
\hline 12 & 7,233 & 0,108 & 0,0102 & 1,353 & 1,338 \\
\hline 16 & 10,100 & 0,128 & 0,0121 & 2,239 & 2,126 \\
\hline 20 & 12,967 & 0,145 & 0,0137 & 3,257 & 2,976 \\
\hline 24 & 15,867 & 0,162 & 0,0153 & 4,452 & 3,938 \\
\hline
\end{tabular}

Perbedaan nilai daya input pada motor menggunakan magnet permanen $15 \mathrm{~mm}$ x $2 \mathrm{~mm}$ dan $20 \mathrm{~mm}$ x $2 \mathrm{~mm}$ dikarenakan nilai arus motor dan tegangan motor yang dihasilkan sehingga, nilai daya input yang dihasilkan pada motor dengan magnet permanen $15 \mathrm{~mm}$ x $2 \mathrm{~mm}$ lebih besar dibandingkan dengan motor dengan menggunakan magnet permanen $20 \mathrm{~mm} \times 2 \mathrm{~mm}$.

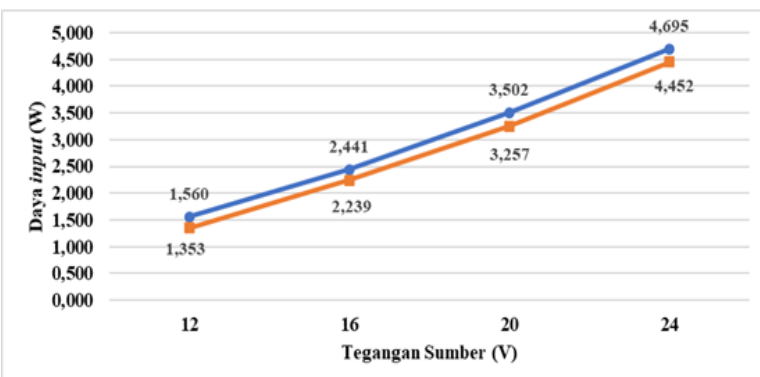

$\rightarrow$ Motor Brushless Direct Current 3 Phase Magnet Permanen $15 \mathrm{~mm} x 2 \mathrm{~mm}$ - -Motor Brushless Direct Current 3 Phase Magnet Permanen 20mm x 2mm

Gambar 10. Karakteristik daya input motor terhadap tegangan sumber pada motor brushless direct current 3 fasa fluks aksial dengan perbedaan diameter magnet permanen tanpa beban

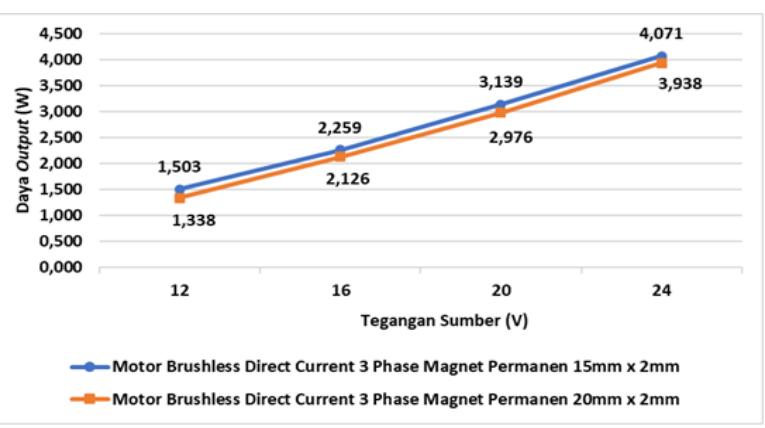

Gambar 11. Karakteristik daya output motor terhadap tegangan sumber pada motor brushless direct current 3 fasa fluks aksial dengan perbedaan diameter magnet permanen tanpa beban 
Pada nilai daya output motor brushless direct current 3 fasa fluks aksial dengan magnet permanen $15 \mathrm{~mm} \times 2 \mathrm{~mm}$ memiliki nilai yang lebih besar dibandingkan dengan menggunakan magnet permanen $20 \mathrm{~mm}$ x $2 \mathrm{~mm}$ dengan nilai tegangan sumber yang sama. Nilai torsi mempengaruhi nilai daya output yang dihasilkan. Sehingga nilai daya output yang dihasilkan motor brushless direct current 3 fasa fluks aksial menggunakan magnet permanen $15 \mathrm{~mm} \times 2 \mathrm{~mm}$ lebih besar dibandingkan daya output pada magnet permanen $20 \mathrm{~mm} \times 2 \mathrm{~mm}$.

Pengujian motor brushless direct current 3 fasa fluks aksial dengan menggunakan beban dilakukan dengan menggunakan beban generator fluks aksial 3 fasa dengan menggunakan LED dan resistor 470 Ohm dengan spesifikasi seperti pada Tabel 8.

Tabel 8. Spesifikasi prototype generator fluks aksial tiga fasa menggunakan magnet permanen neodymium $(\mathrm{NdFeB})$ stator ganda

\begin{tabular}{ccc}
\hline Parameter & Simbol & Nilai \\
\hline Jumlah fasa & $\mathrm{Nph}$ & 3 Phase \\
\hline $\begin{array}{c}\text { Densitas flux } \\
\text { magnet }\end{array}$ & $\mathrm{Br}$ & $0,089 \mathrm{~T}$ \\
\hline Ukuran magnet & $\mathrm{R}$ & $0,75 \mathrm{~cm}$ \\
\hline Ukuran rotor & $\mathrm{T}$ & $0,2 \mathrm{~cm}$ \\
\hline Ukuran stator & $\mathrm{D}$ & $7,2 \mathrm{~cm}$ \\
\hline Diameter kawat & $\mathrm{p}$ & $8 \mathrm{~cm}$ \\
\hline Jarak antar magnet & 1 & $8 \mathrm{~cm}$ \\
\hline Jumlah magnet & $\mathrm{D}$ & $0,5 \mathrm{~mm}$ \\
\hline Jumlah lilitan (tiap & $\mathrm{Nm}$ & $2 \mathrm{~cm}$ \\
\hline kumparan) & $\mathrm{N}$ & $8 \mathrm{magnet}$ \\
\hline Jumlah kumparan & $\mathrm{Ns}$ & $375 \mathrm{lilitan}$ \\
\hline Inti besi & & $12 \mathrm{kumparan}$ \\
\hline Lebar celah udara & & Ya \\
\hline
\end{tabular}

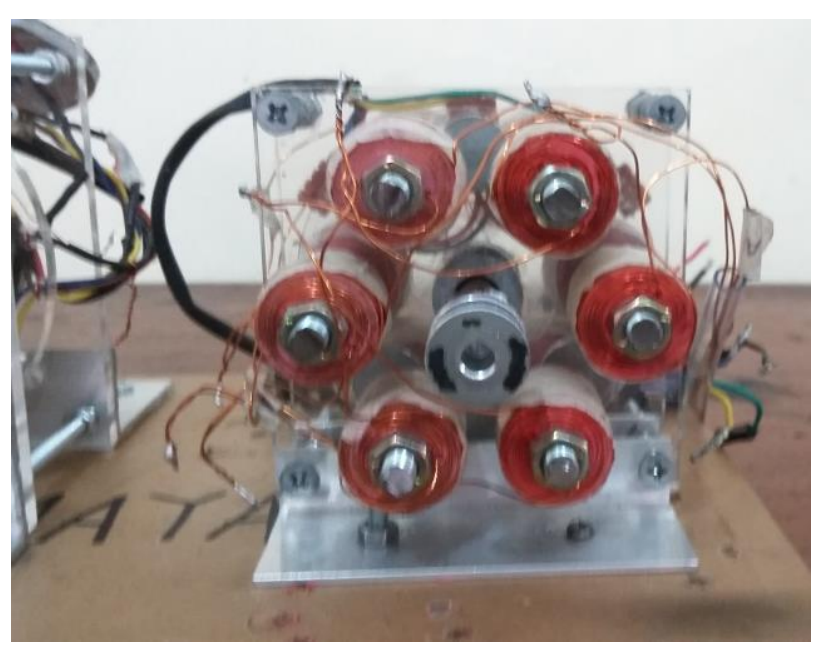

Gambar 12. Generator axial flux tiga fasa menggunakan magnet permanen neodymium (NdFeB) stator ganda
Tabel 9. Hasil pengujian motor brushless direct current 3 fasa fluks aksial magnet permanen $15 \mathrm{~mm}$ x $2 \mathrm{~mm}$ dengan beban

\begin{tabular}{ccccc}
\hline $\begin{array}{c}\text { Tegangan } \\
\text { Sumber } \\
(\mathrm{V})\end{array}$ & $\begin{array}{c}\text { Tegangan } \\
\text { Motor } \\
(\mathrm{V})\end{array}$ & $\begin{array}{c}\text { Arus } \\
\text { Motor } \\
(\mathrm{A})\end{array}$ & $\begin{array}{c}\text { Frekuensi } \\
(\mathrm{Hz})\end{array}$ & $\begin{array}{c}\text { Kecepatan } \\
\text { Motor } \\
(\mathrm{RPM})\end{array}$ \\
\hline 12 & 8,13 & 0,262 & 33,15 & 497 \\
\hline 16 & 11,15 & 0,317 & 46,72 & 696 \\
\hline 20 & 13,89 & 0,363 & 57,73 & 852,7 \\
\hline 24 & 16,69 & 0,39 & 70,42 & 1042 \\
\hline
\end{tabular}

Tabel 10. Hasil pengujian motor brushless direct current 3 fasa fluks aksial magnet permanen $20 \mathrm{~mm}$ x $2 \mathrm{~mm}$ dengan beban

\begin{tabular}{ccccc}
\hline $\begin{array}{c}\text { Tegangan } \\
\text { Sumber } \\
(\mathrm{V})\end{array}$ & $\begin{array}{c}\text { Tegangan } \\
\text { Motor } \\
(\mathrm{V})\end{array}$ & $\begin{array}{c}\text { Arus } \\
\text { Motor } \\
(\mathrm{A})\end{array}$ & $\begin{array}{c}\text { Frekuensi } \\
(\mathrm{Hz})\end{array}$ & $\begin{array}{c}\text { Kecepatan } \\
\text { Motor } \\
(\mathrm{RPM})\end{array}$ \\
\hline 12 & 8,12 & 0,255 & 32,69 & 495,8 \\
\hline 16 & 10,96 & 0,298 & 45,87 & 686 \\
\hline 20 & 13,66 & 0,342 & 57,47 & 867,1 \\
\hline 24 & 17,00 & 0,392 & 71,22 & 1061 \\
\hline
\end{tabular}

Dari Tabel 9 dan 10 dilihat bahwa nilai kecepatan motor brushless direct current 3 fasa fluks aksial dengan magnet permanen $20 \mathrm{~mm} \times 2 \mathrm{~mm}$ dan motor brushless direct current 3 fasa fluks aksial menggunakan magnet permanen $15 \mathrm{~mm}$ x $2 \mathrm{~mm}$ memiliki nilai kecepatan yang hampir sama. Hal yang sama juga berlaku pada nilai frekuensi yang dihasilkan. Perubahan nilai kecepatan dan frekuensi pada pengujian disebabkan oleh penambahan beban generator pada rangkaian.

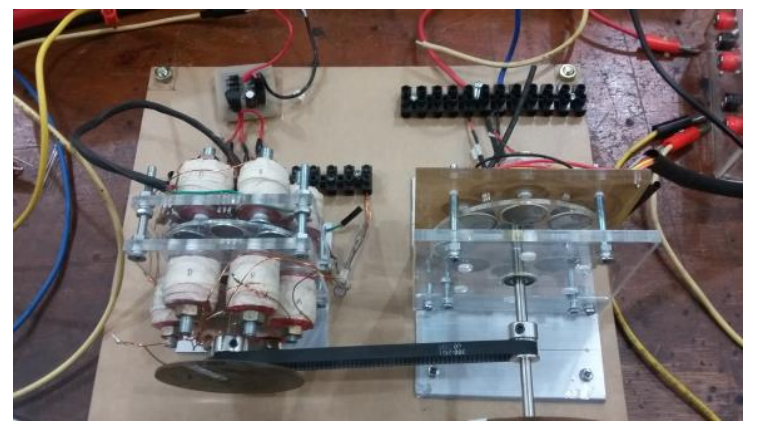

Gambar 13. Rangkaian motor brushless direct current 3 fasa fluks aksial dengan beban generator

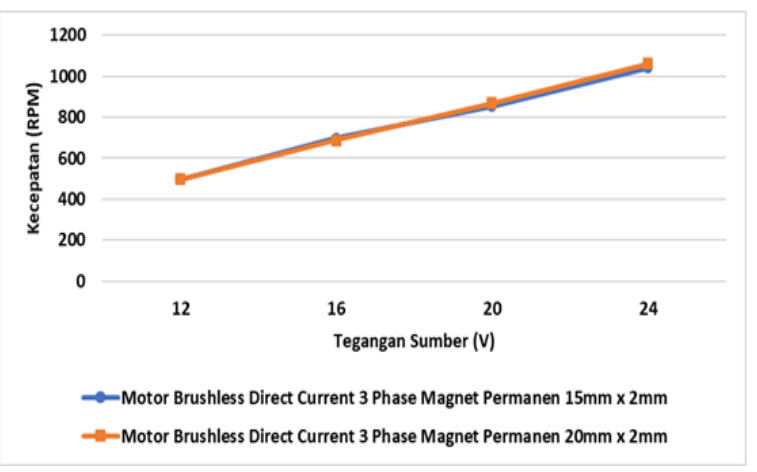

Gambar 14. Karakteristik kecepatan motor terhadap tegangan sumber pada motor brushless direct current 3 fasa fluks aksial dengan beban 
Tabel. 11. Hasil perhitungan torsi motor brushless direct current 3 fasa fluks aksial magnet permanen $15 \mathrm{~mm}$ x $2 \mathrm{~mm}$ dengan beban

\begin{tabular}{ccccc}
$\begin{array}{c}\text { Tegangan } \\
\begin{array}{c}\text { Sumber } \\
(\mathrm{V})\end{array}\end{array}$ & $\begin{array}{c}\text { Tegangan } \\
\text { Motor } \\
(\mathrm{V})\end{array}$ & $\begin{array}{c}\text { Arus } \\
\text { Motor } \\
(\mathrm{A})\end{array}$ & $\begin{array}{c}\text { Gaya } \\
(\mathrm{N})\end{array}$ & $\begin{array}{c}\text { Torsi } \\
(\mathrm{Nm})\end{array}$ \\
\hline 12 & 8,13 & 0,262 & 0,691 & 0,028 \\
\hline 16 & 11,15 & 0,317 & 0,808 & 0,034 \\
\hline 20 & 13,89 & 0,363 & 0,927 & 0,038 \\
\hline 24 & 16,69 & 0,39 & 1,063 & 0,041 \\
\hline
\end{tabular}

Tabel 12. Hasil perhitungan torsi motor brushless direct current 3 fasa fluks aksial magnet permanen $20 \mathrm{~mm}$ x $2 \mathrm{~mm}$ dengan beban

\begin{tabular}{ccccc}
\hline $\begin{array}{c}\text { Tegangan } \\
\begin{array}{c}\text { Sumber } \\
(\mathbf{V})\end{array}\end{array}$ & $\begin{array}{c}\text { Tegangan } \\
\text { Motor } \\
(\mathrm{V})\end{array}$ & $\begin{array}{c}\text { Arus } \\
\text { Motor } \\
(\mathrm{A})\end{array}$ & $\begin{array}{c}\text { Gaya } \\
(\mathrm{N})\end{array}$ & $\begin{array}{c}\text { Torsi } \\
(\mathrm{Nm})\end{array}$ \\
\hline 12 & 8,12 & 0,255 & 0,619 & 0,022 \\
\hline 16 & 10,96 & 0,298 & 0,723 & 0,026 \\
\hline 20 & 13,66 & 0,342 & 0,830 & 0,030 \\
\hline 24 & 17,00 & 0,392 & 0,951 & 0,034 \\
\hline
\end{tabular}

Pada Tabel 11 dan Tabel 12 menyajikan data nilai torsi dan gaya pada motor brushless direct current 3 fasa fluks aksial dengan menggunakan magnet permanen $15 \mathrm{~mm} \mathrm{x}$ $2 \mathrm{~mm}$ dan $20 \mathrm{~mm} \times 2 \mathrm{~mm}$. Nilai torsi yang dihasilkan oleh motor brushless direct current 3 fasa fluks aksial saat menggunakan magnet permanen dengan ukuran $15 \mathrm{~mm} \mathrm{x}$ $2 \mathrm{~mm}$ lebih besar bila dibandingkan dengan motor dengan magnet permanen berukuran $20 \mathrm{~mm}$ x $2 \mathrm{~mm}$. Gambar 15 menyajikan grafik hubungan natara kecepatan dengan tegangan sumber saat pengujian motor brushless direct current 3 fasa fluks aksial dengan menggunakan beban.

Pada Tabel 13 dan 14 nilai daya input dan daya output pada pengujian motor brushless direct current 3 fasa fluks aksial dengan magnet permanen $15 \mathrm{~mm}$ x $2 \mathrm{~mm}$ lebih besar dibandingkan dengan motor dengan menggunakan magnet permanen $20 \mathrm{~mm}$ x $2 \mathrm{~mm}$. Nilai daya input dan output pada pengujian motor brushless direct current 3 fasa fluks aksial memiliki nilai selisih yang besar.

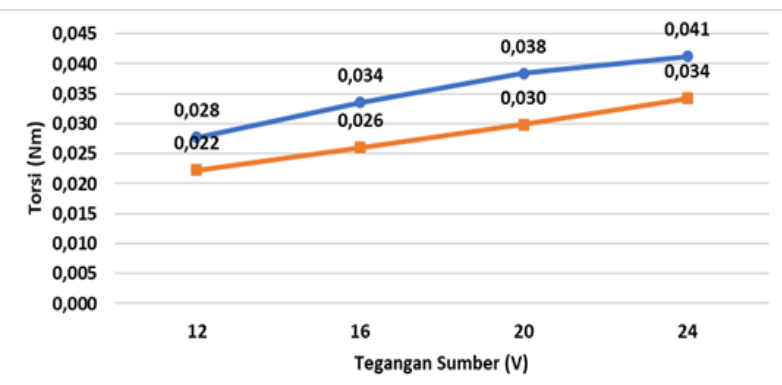

- Motor Brushless Direct Current 3 Phase Magnet Permanen $15 \mathrm{~mm} \times 2 \mathrm{~mm}$ - - Motor Brushless Direct Current 3 Phase Magnet Permanen $20 \mathrm{~mm} \times 2 \mathrm{~mm}$

Gambar 15. Karakteristik torsi motor terhadap tegangan sumber pada motor brushless direct current 3 fasa fluks aksial dengan beban
Tabel. 13. Hasil perhitungan daya input dan daya output motor brushless direct current 3 fasa fluks aksial magnet permanen

$15 \mathrm{~mm} \times 2 \mathrm{~mm}$ dengan beban

\begin{tabular}{cccccc}
$\begin{array}{c}\text { Tegangan } \\
\text { Sumber } \\
(\mathrm{V})\end{array}$ & $\begin{array}{c}\text { Tegangan } \\
\text { Motor } \\
(\mathrm{V})\end{array}$ & $\begin{array}{c}\text { Arus } \\
\text { Motor } \\
(\mathrm{A})\end{array}$ & $\begin{array}{c}\text { Torsi } \\
(\mathrm{Nm})\end{array}$ & $\begin{array}{c}\text { Daya } \\
\text { Input } \\
(\mathrm{W})\end{array}$ & $\begin{array}{c}\text { Daya } \\
\text { Output(W) }\end{array}$ \\
\hline 12 & 8,13 & 0,262 & 0,028 & 3,688 & 1,441 \\
\hline 16 & 11,15 & 0,317 & 0,034 & 6,122 & 2,441 \\
\hline 20 & 13,89 & 0,363 & 0,038 & 8,733 & 3,424 \\
\hline 24 & 16,69 & 0,39 & 0,041 & 11,276 & 4,496 \\
\hline
\end{tabular}

Tabel 14. Hasil perhitungan daya input dan daya output motor brushless direct current 3 fasa fluks aksial magnet permanen $20 \mathrm{~mm} \times 2 \mathrm{~mm}$ dengan beban

\begin{tabular}{cccccc}
\hline $\begin{array}{c}\text { Tegangan } \\
\begin{array}{c}\text { Sumber } \\
(\mathrm{V})\end{array}\end{array}$ & $\begin{array}{c}\text { Tegangan } \\
\text { Motor } \\
(\mathrm{V})\end{array}$ & $\begin{array}{c}\text { Arus } \\
\text { Motor } \\
(\mathrm{A})\end{array}$ & $\begin{array}{c}\text { Torsi } \\
(\mathrm{Nm})\end{array}$ & $\begin{array}{c}\text { Daya } \\
\text { Input } \\
(\mathrm{W})\end{array}$ & $\begin{array}{c}\text { Daya } \\
\text { Output } \\
(\mathrm{W})\end{array}$ \\
\hline 12 & 8,12 & 0,255 & 0,022 & 3,588 & 1,156 \\
\hline 16 & 10,96 & 0,298 & 0,026 & 5,657 & 1,869 \\
\hline 20 & 13,66 & 0,342 & 0,030 & 8,094 & 2,712 \\
\hline 24 & 17,00 & 0,392 & 0,034 & 11,542 & 3,803
\end{tabular}

Nilai daya input yang besar dipengaruhi oleh nilai arus yang tinggi. Nilai arus pada saat pengujian motor brushless direct current 3 fasa fluks aksial lebih besar dibandingkan saat pengujian motor brushless direct current 3 fasa fluks aksial diuji tanpa menggunakan beban sedangkan, besarnya nilai daya output dikarenakan nilai torsi yang dimiliki semakin besar. Gambar 16 dan Gambar 17 menunjukkan perbedaan nilai daya input dan daya output terhadap setiap kenaikan tegangan sumber.

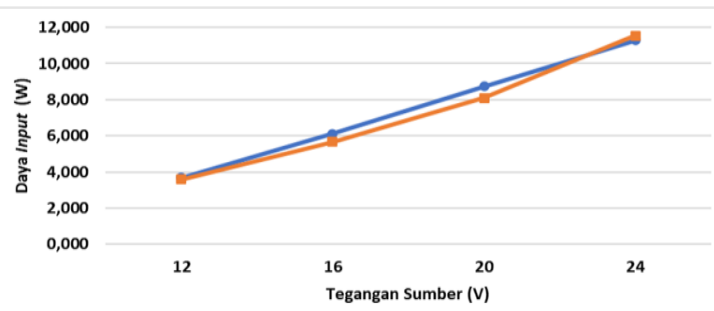

-Motor Brushless Direct Current 3 Phase Magnet Permanen $15 \mathrm{~mm} \times 2 \mathrm{~mm}$ $=-$ Motor Brushless Direct Current 3 Phase Magnet Permanen $20 \mathrm{~mm} \times 2 \mathrm{~mm}$

Gambar 16. Karakteristik daya input motor terhadap tegangan sumber pada motor brushless direct current 3 fasa fluks aksial menggunakan beban

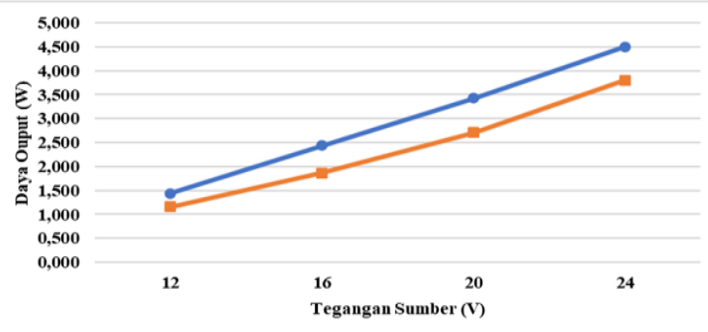

Motor Brushless Direct Current 3 Phase Magnet Permanen 15mm x 2m - - Motor Brushless Direct Current 3 Phase Magnet Permanen 20mm x 2mm

Gambar 17. Karakteristik daya output motor terhadap tegangan sumber pada motor brushless direct current 3 fasa fluks aksial menggunakan beban 
Tabel 16. Hasil perhitungan efisiensi daya motor brushless direct current 3 fasa fluks aksial dengan perbedaan diameter magnet

\begin{tabular}{|c|c|c|c|c|}
\hline Tegangan & $\begin{array}{l}\text { Magnet } \\
\text { Permanen } \\
15 \mathrm{~mm} \mathrm{x} \\
2 \mathrm{~mm}\end{array}$ & $\begin{array}{l}\text { Magnet } \\
\text { Permanen } \\
20 \mathrm{~mm} \mathrm{x} \\
2 \mathrm{~mm}\end{array}$ & $\begin{array}{c}\text { Magnet } \\
\text { Permanen } \\
15 \mathrm{~mm} \mathrm{x} \\
2 \mathrm{~mm}\end{array}$ & $\begin{array}{c}\text { Magnet } \\
\text { Permanen } \\
20 \mathrm{~mm} \mathrm{x} \\
2 \mathrm{~mm}\end{array}$ \\
\hline & $\begin{array}{l}\text { Tanpa } \\
\text { Beban } \\
(\%)\end{array}$ & $\begin{array}{c}\text { Tanpa } \\
\text { Beban } \\
(\%)\end{array}$ & $\begin{array}{c}\text { Dengan } \\
\text { Beban } \\
(\%)\end{array}$ & $\begin{array}{c}\text { Dengan } \\
\text { Beban } \\
(\%)\end{array}$ \\
\hline $12 \mathrm{~V}$ & 96,314 & 98,918 & 39,063 & 32,223 \\
\hline $16 \mathrm{~V}$ & 92,559 & 94,966 & 39,871 & 33,045 \\
\hline $20 \mathrm{~V}$ & 89,650 & 91,394 & 39,212 & 33,504 \\
\hline $24 \mathrm{~V}$ & 86,724 & 88,460 & 39,870 & 32,950 \\
\hline
\end{tabular}

Pada Gambar 16 merupakan grafik karakteristik efisiensi motor brushless direct current 3 fasa fluks aksial dimana nilai efisiensi tertinggi didapat saat motor menggunakan magnet permanen $20 \mathrm{~mm}$ x $2 \mathrm{~mm}$ dengan nilai pengujian tanpa beban sebesat $98 \%$ dan nilai efisiensi terrendah didapat saat motor menggunakan magnet permanen $20 \mathrm{~mm} \times 2 \mathrm{~mm}$ dengan pengujian dengan beban. Dengan nilai 32,223\%. Nilai efisiensi daya dipengaruhi oleh perbedaan nilai daya input dan daya output yang dihasilkan.

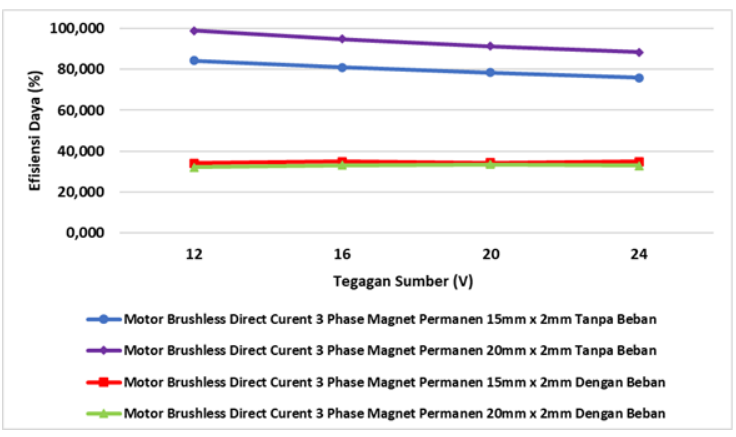

Gambar 18. Karakteristik efisiensi motor brushless direct current 3 fasa fluks aksial setiap pengujian terhadap setiap kenaikan tegangan sumber

\section{KESIMPULAN}

Setelah dilakukan penelitian mengenai pengaruh diameter magnet permanen terhadap performa motor didapat beberapa kesimpulan bahwa nilai kecepatan saat pengujian motor brushless direct current 3 fasa fluks aksial dengan menggunakan magnet permanen $20 \mathrm{~mm} \mathrm{x}$ $2 \mathrm{~mm}$ lebih besar bila dibandingkan dengan kecepatan motor brushless direct current 3 fasa fluks aksial dengan menggunakan magnet permanen $15 \mathrm{~mm}$ x $2 \mathrm{~mm}$ sedangkan, nilai torsi pada motor brushless direct current 3 fasa fluks aksial saat menggunakan magnet permanen $20 \mathrm{~mm} \times 2 \mathrm{~mm}$ lebih kecil dibandingkan saat menggunakan magnet permanen dengan ukuran $15 \mathrm{~mm} \mathrm{x}$ $2 \mathrm{~mm}$. Hal ini disebabkan perbedaan nilai medan magnet pada sisi rotor.

Pada pengujian motor brushless direct current 3 fasa fluks aksial menggunakan tanpa menggunakan beban, nilai kecepatan, torsi dan daya yang dihasilkan lebih besar bila dibandingkan dengan pengujian motor brushless direct current 3 fasa fluks aksial menggunakan beban. Nilai efisiensi tertinggi didapat saat motor brushless direct current 3 fasa fluks aksial dengan menggunakan magnet permanen $20 \mathrm{~mm}$ x $2 \mathrm{~mm}$ tanpa beban sebesar 98,18\% dan efisiensi terkecil didapat saat motor brushless direct current 3 fasa fluks aksial dengan magnet permanen $20 \mathrm{~mm}$ x $2 \mathrm{~mm}$ dengan beban sebesar $32,2 \%$.

\section{UCAPAN TERIMA KASIH}

Kami mengucapkan banyak terimakasih kepada semua pihak yang telah membantu dan berkontribusi dalam pembuatan penelitian ini. Terimakasih kepada keluarga Laboratorium Konversi Energi Listrik telah memfasilitasi pembuatan alat pada penelitian ini. Tidak lupa, terimakasih kepada ELKHA atas fasiltas dan penerbitan jurnal Performance Test of Three-Phase Brushless Direct Current Motor Axial Flux with Differences Diameter of Neodymium Type Permanent Magnet

\section{DAFTAR PUSTAKA}

[1] Z. Abidin, T. Priangkoso, and D. Darmanto, "Pengujian Performance Motor Listrik Ac 3 Fasa Dengan Daya $3 \mathrm{Hp}$ Menggunakan Pembebanan Generator Listrik," $J$. Momentum UNWAHAS, vol. 9, no. 1, pp. 30-34, 2013.

[2] A. Kurniawan Rizky, "Rancang Bangun Motor Searah Tanpa Sikat Satu Fasa," University of Jember, 2016.

[3] M. Reqzy, "Rancang Bangun Motor Brushless Direct Current 3 Phase Fluks Axial," University of Jember, 2020.

[4] W.B. Pramono, H. P. Pratama, and Warindi, "Perancangan Motor Litrik BLDC 10KW Untuk sepeda Motor Listrik," Semin. Nas. Teknol. dan Inform., vol. 3, pp. 113-120, 2016.

[5] R. Afif, “Analisis Frekuensi Terhadap Kecepatan Motor BLDC ( Brushless Direct Current) Satu Fasa Kontruksi Axial Flux Celah Udara Tunggal,” pp. 1-4, 2020.

[6] A. Nurtriartono, "Rancang Bangun Dan Uji Peforma Axial Brushless DC Motor Dengan Daya Output 2000 Watt," Inst. Teknol. Sepuluh Nop., 2014.

[7] M. Gussow, Theory and Problems of Basic Electricity. 1983.

[8] T. Kenjō and S. Nagamori, Permanent-magnet and brushless DC motors. 1985.

[9] E. Prasetyo, "Analisis Pengaruh Jatuh Tegangan Jala-Jala Terhadap Unjuk Kerja Motor Induksi Tiga Fasa", 2016. 